\title{
ANALISIS DAMPAK LALU LINTAS AKIBAT PEMBANGUNAN WISATA ALAM DESA MEDOWO KECAMATAN KANDANGAN KEDIRI
}

\author{
Maulida Nurunnafissa \\ Teknik Sipil, Fakultas Teknik, Universitas Hasyim Asy’ari, Email : nafissamaulida@ gmail.com
}

Tri Rijanto

Fakultas Teknik, Universitas Hasyim Asy’ari, Email : tririjanto@unesa.ac.id

\begin{abstract}
Abdiyah Amudi
Teknik Sipil, Fakultas Teknik, Universitas Hasyim Asy’ari, Email : abdiyah.amudi@yahoo.com
\end{abstract}

\section{Abstrak}

Desa Medowo merupakan salah satu Desa di Kecamatan Kandangan yang berada di daerah perbukitan. Keadaan geografis Desa Medowo menjadikan Desa tersebut memiliki berbagai macam lahan perbukitan yang sangat indah dan subur. Beberapa diantaranya adalah Wisata Alam Bukit Gandrung, Wisata Alam Plengsengan Refreshing Hill (PRH), dan Wisata Alam Air Terjun Sumber Jodo. Dengan adanya pariwisata tersebut membuat arus lalu lintas meningkat pada jam-jam sibuk. Kurangnya fasilitas pendukung infrastuktur di sekitar lokasi wisata alam menjadikan berkurangnya kenyamanan yang dirasakan oleh pengguna jalan.

Untuk mengetahui dampak lalu lintas di ketiga ruas jalan tersebut, maka dilakukan penelitian kinerja lalu lintas beserta analisisnya menggunakan metode MKJI 1997 dan analisis SWOT Balanced Scorecard. Dari hasil perhitungan kinerja lalu lintas diketiga ruas jalan didapatkan hasil tingkat pelayanan jalan A atau Level Of Service (LOS) senilai 0,02 - 0,03 dan analisis dampak menggunakan SWOT Balanced Scorecard mengacu pada 4 (empat) kriteria yakni kekuatan, kelamahan, peluang, dan ancaman.

Kata Kunci: Dampak lalu lintas, Pariwisata alam, Kapasitas, Tingkat pelayanan.

\section{Abstract}

Medowo village is one of the villages in Kandangan Districts residing in hilly area. Geographical circumstances make the Medowo Village has a variety of picturesque hills land and fertile. Some of which are nature tourism, nature tourism Gandrung Hill, Plengsengan Refreshing Hill (PRH), and Waterfall Sumber Jodo. The existence of the tourism traffic flow increasing at rush-hour. Lack of supporting facilities infrastructure around natural tourism makes the reduced comfort felt by road users.

To find out the impact of traffic on the roads of the third, then conducted the research along with traffic performance analysis using the method of MKJI 1997 and the Balanced Scorecard SWOT analysis. From the results of the calculation of the performance of the traffic road of in the third obtained the results of A road level of service or Level Of Service (LOS) worth 0.02 - 0.03 impact analysis using SWOT and Balanced Scorecard refers to the four (4) criteria i.e. strengths, weaknesses, opportunities, and threats.

\section{PENDAHULUAN}

Indonesia merupakan negara tropis dengan keanekaragaman hayati. Bagi masyarakat Indonesia ataupun luar Indonesia, keadaan topografi dan geografi yang dimiliki sangat baik untuk dapat dimanfaatkan, contohnya adalah pemanfaatan untuk objek wisata berbasis alam.

Kabupaten Kediri merupakan Kabupaten yang sebagian besar penduduknya bekerja pada sektor pertanian dan perdagangan yang memerlukan moda transportasi untuk mobilisasi. Kabupaten Kediri dengan luas $1.386,05 \mathrm{~km}^{2}$ dengan pertumbuhan penduduk yang semakin bertambah setiap tahunnya tidak sebanding dengan ketersediaan moda transportasi dan lokasi wisata. Untuk daerah Kabupaten Kediri sendiri, setidaknya memiliki sekitar 30 objek wisata berbasis alam terbuka seperti Wisata Gunung Kelud, Wisata Air Terjun Dolo, Wisata Goa Selomangleng, Wisata Bukit jambu, dan lain sebagainya. Selain beberapa wisata yang baik untuk angkutan umum maupun angkutan pribadi yang pada masa mendatang atau pada tahun rencana akan digunakan berbagai kebijakan perencanaan transportasi (Tamin, 2000).

Tujuan dari penelitian ini adalah:

(1) Mengetahui dampak lalu lintas yang terjadi akibat dari adanya pembangunan wisata alam Desa Medowo.

(2) Mengetahui kinerja lalu lintas yang ada disekitar kawasan wisata alam Desa Medowo. 
(3) Memberikan strategi perencanaan yang dapat membantu mengurangi dampak lalu lintas akibat pembangunan wisata alam Desa Medowo Kecamatan Kandangan Kediri.

\section{TINJAUAN PUSTAKA}

\section{Penelitian Terdahulu}

Untuk memperkuat penelitian ini, maka penulis mengambil dan mengangkat beberapa penelitian terdahulu yang serupa yaitu:

(1) Analisis Dampak Lalu Lintas Akibat Adanya Pusat Perbelanjaan dikawasan Pasar Pagi Pangkalpinang terhadap Kinerja Ruas Jalan (Feby Ayu Lestari, 2014. Jurnal Teknik Sipil Vol. 2 No. 1). Membahas mengenai dampak lalu lintas yang terjadi di pusat perbelanjaan kawasan pasar pagi Pangkalpinang menghasilkan kesimpulan yakni kinerja lalu lintas dipengaruhi oleh kegiatan di Kawasan Pasar Pagi Pangkalpinang khususnya di ruas jalan yang sering kali dimanfaatkan sebagai lahan parkir. Teknik analisa yang dipakai adalah dengan survei dan MKJI 1997.

(2) Studi Evaluasi Dampak Lalu Lintas Akibat Pembangunan Stasiun Pengisian Bahan Bakar Umum (SPBU) Manahan Surakarta (Slamet Jauhari Legowo, Amirotul MHM, Doni Aggoro, 2014. e-Jurnal Matriks Teknik Sipil). Membahas mengenai dampak lalu lintas akibat adanya pembangunan Stasiun Pengisian Bahan Bakar Umum (SPBU) di daerah Surakarta menghasilkan kesimpulan bahwa pembangunan Stasiun pengisian Bahan Bakar Umum (SPBU) Manahan Surakarta, tidak terlalu berdampak pada lalu lintas di sekitar simpang 4. Aktivitas bisa dikatakan stabil. Teknik analisa yang dipakai adalah survei, MKJI 1997, dan VCR.

(3) Analisa Dampak Pembangunan Hotel Ibis Manado terhadap Lalu Lintas di Jalan Piere Tendean Manado (F.C Woran, 2015. Jurnal Ilmiah Media Engineering Vol. 5 No. 1). Membahas mengenai dampak pembangunan Hotel Ibis Manado terhadap lalu lintas di Jalan Piere Tendean Manado dengan hasil penelitian yakni volume kendaraan saat hotel beroperasi yakni tahun 2016 berada pada tingkat pelayanan D $(0,75-0,84)$, arus mendekati tidak stabil namun kecepatan masih bisa dikendalikan. Teknik analisa yang dipakai adalah survei dan MKJI 1997.

(4) Analisa Dampak Lalu Lintas (Andalalin) Kawasan Lippo Plaza Kairagi Manado (Tonaas Rantung, 2016. Jurnal Ilmiah Media Engineering Vol. 5 No.1). Membahas mengenai dampak lalu lintas kawasan Lippo Plaza Kairagi Manado yang menghasilkan kesimpulan bahwa pembangunan kawasan Lippo Plaza Kairagi Manado tidak terlalu berpengaruh terhadap lalu lintas, yakni arus masih terbilang stabil dengan tingkat pelayanan adalah C. Teknik analisa yang dipakai adalah survei dan MKJI 1997.

(5) Studi Dampak Lalu Lintas Kawasan Akibat Pembangunan Jalan Layang (Flyover) Simpang Surabaya dan Jalan Lintas Bawah (Underpass) Kuta Alam Kota Banda Aceh (Dedek Ariansyah, Sugiarto, Sofyan M Saleh, 2017. Jurnal Teknik Sipil Vol. 1 No. 1). Membahas mengenai dampak lalu lintas akibat adanya pembangunan jalan layang Simpang Surabaya dan jalan lintas bawah dengan hasil penelitian bahwa terjadi peningkatan volume kendaraan sebelum dan sesudah Pembangunan Jalan Layang (Flyover) Simpang Surabaya dan Jalan Lintas Bawah (Underpass) Kuta Alam Banda Aceh, terjadi peningkatan sebesar pada Jalan Teuku Muhammad Hasan sebesar 16,31\%, dan Jalan Teuku Hasan Dek sebesar $1,40 \%$ sedangkan penurunan arus lalu lintas selama masa konstruksi terdapat pada Jalan Teuku Iskandar sebesar $-23,05 \%$. Teknik analisa yang dipakai adalah survei dan MKJI 1997.

\section{Dampak Lalu Lintas}

Analisis dampak lalu lintas pada dasarnya merupakan analisis pengaruh pengembangan tata guna lahan terhadap sistem pergerakan arus lalu lintas di sekitarnya yang diakibatkan oleh bangkitan lalu lintas yang baru, lalu lintas yang beralih, dan oleh kendaraan keluar/masuk dan dari/ke lahan tersebut (Tamin 2000).

Tujuan analisis dampak lalu lintas adalah:

(1) Memprediksi suatu dampak yang ditimbulkan akibat pembangunan suatu kawasan

(2) Menentukan bentuk peningkatan atau perbaikan yang diperlukan untuk mengakomodasi perubahan yang terjadi

(3) Menyelaraskan keputusan-keputusan mengenai tata guna lahan dengan kondisi lalu lintas, lokasi, dan alternatif perbaikan

(4) Memprediksi suatu dampak yang ditimbulkan akibat pembangunan suatu kawasan

Adapun langkah-langkah penanganan masalah adalah sebagai berikut:

(1) Do nothing, tidak melakukan kegiatan pada kondisi jaringan jalan yang ada

(2) Do minimum, manajemen lalu lintas atau mengoptimalkan prasarana tersedia, dengan melakukan re-cycle simpang bersinyal, memasang rambu, marka, dll

(3) Do something, melaksanakan upaya peningkatan, perbaikan geometrik ruas dan 
simpang atau pembangunan jalan baru (interchange pada simpang)

\section{METODE}

Lokasi penelitian terletak di Desa Medowo Kecamatan Kandangan Kabupaten Kediri tepatnya di tiga ruas jalan menuju lokasi objek wisata yang memiliki panjang ruas jalan berbeda-beda. Teknik analisis yang digunakan pada penelitian ini adalah analisis LOS (Level Of Service) dan metode SWOT Balanced Scorecard. Variabel yang digunakan dalam penelitian ini adalah faktor kenyamanan, keamanan, kesenangan, daya tarik, dan geometrik (Tabel 1). Analisis Level Of Service (LOS) merupakan tingkat pelayanan menyatakan tingkat kualitas arus lalu lintas yang terjadi. Tingkat ini dinilai oleh penumpang berdasarkan tingkat kemudahan dan kenyamanan pengemudi, baik dalam hal kebebasan menentukan kecepatan, kebebasan menentukan waktu perjalanan, kebebasan untuk maneuver, kenyamanan pengemudi, dan biaya perjalanan. Sehingga, LOS merupakan sebagai tolak ukur kualitas suatu jalan yang mengacu kepada tingkat pelayanan jalan dengan nilai $\mathrm{A}$ sampai $\mathrm{F}$ bergantung dari hasil perhitungan LOS yang didapat.

\begin{tabular}{|c|c|}
\hline $\begin{array}{l}\text { Variabel } \\
\text { Penelitian }\end{array}$ & Sub Variabel \\
\hline $\begin{array}{l}\text { Kenyamanan } \\
\text { (Comfort) }\end{array}$ & $\begin{array}{l}\text { - Fasilitas infrastruktur } \\
\text { - Bahu jalan } \\
\text { - Lampu penerangan }\end{array}$ \\
\hline $\begin{array}{l}\text { Keamanan } \\
\text { (Safety) }\end{array}$ & $\begin{array}{l}\text { - Perbaikan kerusakan pada } \\
\text { beberapa titik ruas jalan } \\
\text { - Rambu-rambu lalu lintas } \\
\text { - Pembatas tepi jalan } \\
\end{array}$ \\
\hline $\begin{array}{l}\text { Kesenangan } \\
\text { (Conveience) }\end{array}$ & $\begin{array}{l}\text { - Keseimbangan antara lebar } \\
\text { jalur denga kapasitas jalan } \\
\text { - Jarak yang terjangkau dari } \\
\text { lokasi pemukiman }\end{array}$ \\
\hline Daya Tarik & $\begin{array}{l}\text { - Penataan tata guna lahan yang } \\
\text { baik dan menarik } \\
\text { - Pemilihan desain yang sesuai } \\
\text { dengan kondisi lokasi }\end{array}$ \\
\hline $\begin{array}{l}\text { Geometrik } \\
\text { (Geometric) }\end{array}$ & $\begin{array}{l}\text { - Ketinggian dan turunan pada } \\
\text { infrastruktur jalan yang sesuai } \\
\text { dengan kondisi geometrik }\end{array}$ \\
\hline
\end{tabular}

Berikut beberapa tahapan perhitungan dalam metode ini antara lain (MKJI 1997):

(1) Volume arus lalu lintas (smp)

(2) Kapasitas ruas jalan $\mathrm{C}=C_{\mathbb{Q}} \times F C_{W} \times F C_{S P} x F C_{S F} \times F C_{C S}(1)$
Dimana:

$$
\begin{aligned}
\mathbf{C} & =\text { Kapasitas } \\
\mathrm{C}_{0} & =\text { kapasitas dasar (smp/jam) } \\
\mathrm{FC}_{W} & =\text { faktor penyesuaian lebar jalur lalu lintas } \\
\mathrm{FC}_{5 P} & =\text { faktor penyesuaian pemisahan arah } \\
\mathrm{FC}_{\text {SE }} & =\text { faktor penyesuaian hambatan samping } \\
\mathrm{FC}_{\mathrm{CS}} & =\text { faktor penyesuaian ukuran kota }
\end{aligned}
$$

(3) Tingkat pelayanan jalan

$$
\mathrm{DS}=\mathrm{Q} / \mathrm{C}
$$$$
\text { Dimana: }
$$

$\mathrm{Q}=$ volume arus lalu lintas

$\mathrm{C}=$ kapasitas ruas jalan

(4) Kecepatan arus bebas

$$
\mathrm{FV}=\left(F V_{0}+F V_{W}\right) x F F V_{S F} x F F V_{C S}
$$

Dimana:

$\mathrm{FV}=$ kecepatan arus bebas kendaraan ringan pada kondisi lapangan ( $\mathrm{km} / \mathrm{jam})$

$\mathrm{FV}_{0}=$ kecepatan arus bebas dan dasar kendaraan ringan pada jalan dan alinyemen yang diamati ( $\mathrm{km} / \mathrm{jam})$

$\mathrm{FV}_{W}=$ penyesuaian kecepatan akibat lebar jalur lalu lintas

$\mathrm{FFV}_{\text {SF }}=$ faktor penyesuaian hambatan samping dan lebar bahu/kerb ke penghalang $\mathrm{FFV}_{\mathrm{CS}}=$ faktor penyesuaian ukuran kota

Kemudian, untuk menentukan strategi perencanaan kinerja lalu lintas di ketiga ruas jalan wisata alam Desa Medowo Kecamatan Kandangan Kediri menggunakan analisis Scenario Planning dengan metode SWOT Balanced Scorecard. Analisis Scenario Planning dimaksudkan untuk merumuskan beberapa variabel yang telah didapatkan untuk merencanakan strategi dan diterapkan di ketiga ruas jalan wisata alam Desa Medowo.

(1) Dalam merumuskan Scennario Planning diperlukan beberapa langkah yang perlu dilakukan, yaitu: Identify Focal Issue, dimana peneliti harus mengidentifikasi isu utama yang ada untuk menjadi fokus utama permasalahan yang harus dijawab.

(2) Identify Key Forces, yaitu identifikasi faktorfaktor kunci seperti variabel yang diperkirakan mempengaruhi focal issue di kemudian.

(3) Identify Driving Forces. Langkah yang ketiga yaitu mampu mengidentifikasi kekuatankekuatan yang dapat mendorong perubahan berkaitan dengan key forces.

Scenario Planning pada tahapan ini menggunakan metode SWOT Balanced Scorecard. Analisis SWOT Balanced Scorecard adalah suatu metode yang digunakan untuk mengkaji dan mengevaluasi kekuatan (strengths), kelemahan (weaknesses), peluang

(opportunities), dan ancaman (threats) dalam suatu proyek atau kegiatan bisnis yang dapat digunakan untuk menyusun sebuah rencana tepat guna untuk mencapai tujuan yang penjabarannya bersifat deskriptif. Balanced 
Scorecard adalah skor yang digunakan untuk mengukur kinerja dengan cara memperhatikan keseimbangan antara sisi keuangan dan non keuangan, antara jangka pendek dan jangka panjang serta melibatkan faktor internal dan eksternal. Proses pelaksanaan metode SWOT Balanced Scorecard adalah sebagai berikut (Rangkuti, 2011):

(1) Melakukan proses input untuk menyusun SWOT Balanced Scorecard

(2) Mengembangkan timeline (ketepatan waktu)

(3) Kuisioner

(4) Identifikasi penyebab masalah

(5) Menentukan tujuan dan sasaran strategis

(6) Menyusun isu strategis, formulasi strategis, tema strategis, dan pemetaan strategis

(7) Menentukan ukuran yang dipakai dalam SWOT Balanced Scorecard

(8) Memberikan bobot dan nilai kinerja

(9) Analisis resiko, anggaran (jika diperlukan), analisis kasus.

\section{HASIL DAN PEMBAHASAN}

1. Gambaran Umum

Secara geografis Kabupaten Kediri terletak antara $111^{\circ} 47^{\prime} 05$ " s/d $112^{\circ} 18^{\prime \prime} 20^{\prime \prime}$ Bujur Timur dan antara
7³6"12" s/d 80"32" Lintang Selatan. Luas wilayah Kabupaten Kediri adalah 1.386,05 km² atau $138.605 \mathrm{Ha}$ dengan total populasi pada tahun 2015 sebanyak 1.546.883 jiwa dengan total 26 Kecamatan. Sedangkan Desa Medowo merupakan salah satu Desa yang ada di Kecamatan Kandangan Kabupaten Kediri . Wisata alam yang berada di Desa Medowo Kecamatan Kandangan Kabupaten Kediri berada di tiga lokasi yang berbeda. Ketiga ruas jalan menuju lokasi wisata tersebut merupakan jalan lokal dengan struktur jalan tersebut bervariasi, mulai dari makadam, beton rigid, dan aspal hotmix dengan rerata lebar jalan 2 sampai 3,5 meter. Fungsi dan peranan ketiga ruas jalan tersebut sebagai penghubung. Jaringan jalan menuju ketiga lokasi wisata tersebut merupakan salah satu urat nadi perekonomian di Desa Medowo, dengan fungsinya sebagai penghubung perekonomian warga. Pola jaringan jalan tidak sama, hal tersebut dikarenakan pengaruh kondisi geografi dan tata guna lahan. Demikian pula dengan ketiga ruas jalan menuju lokasi wisata alam Desa Medowo, memiliki karakteristik berbeda yang juga dipengaruhi oleh kondisi geografisnya.
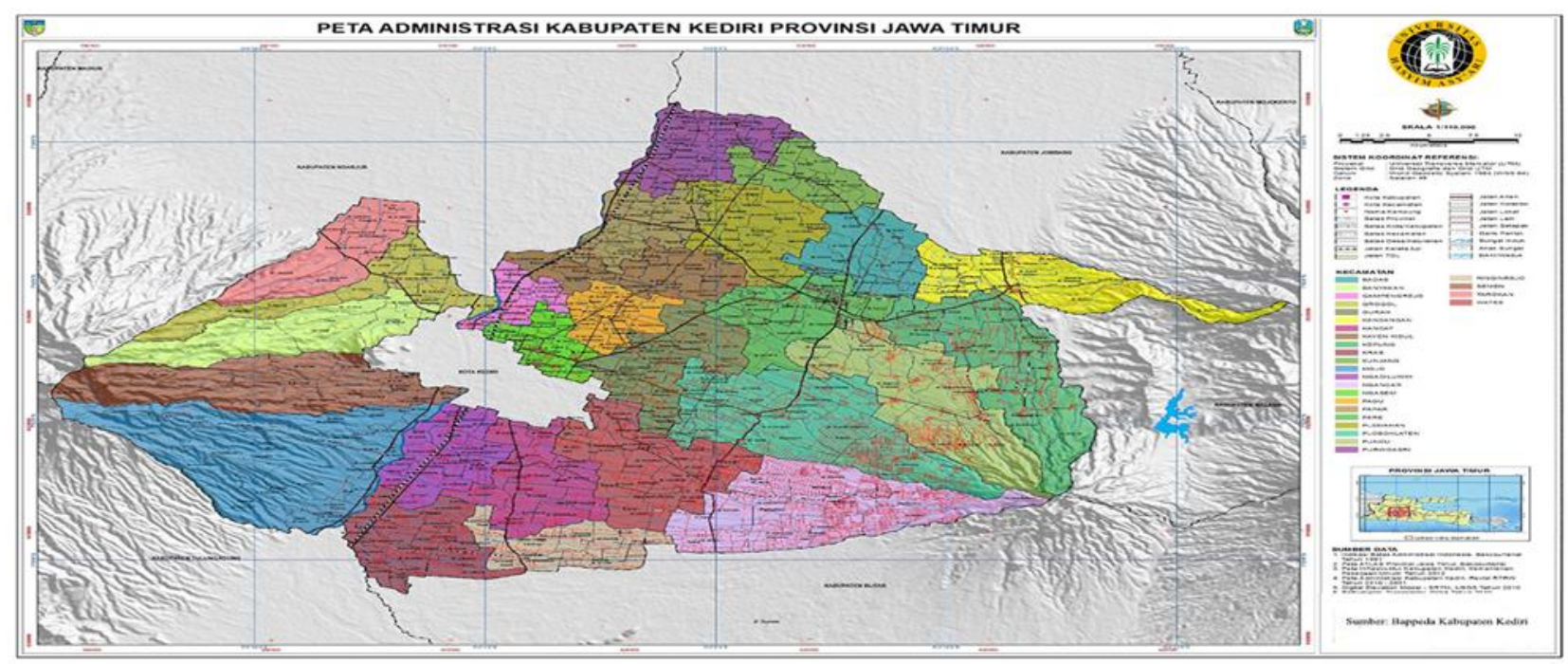

Gambar 1. Peta Administrasi Kabupaten Kediri.

\section{Analisis Geometrik Jalan}

Deskripsi data geometrik ruas jalan wisata alam Desa Medowo Kecamatan Kandangan Kediri menguraikan mengenai kondisi ekxisting dari ketiga ruas jalan dan hambatan samping yang mempengaruhi kapasitas jalan. Ruas jalan wisata alam Desa Medowo memiliki lebar dan panjang yang berbeda, bergantung dari lokasi dan keadaan geografinya. Keterangan lebih jelas bisa dilihat pada masing-masing gambar, penampang melintang ruas jalan Bukit Gandrung (Gambar 2), penampang melintang ruas jalan Plengsengan Refreshing Hill (PRH) (Gambar 3), dan penampang melintang ruas jalan Air Terjun Sumber Jodo (Gambar 4).

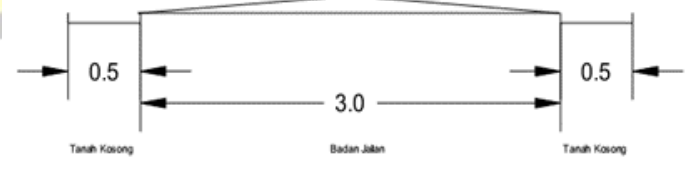

Ket. dalam satuan meter 


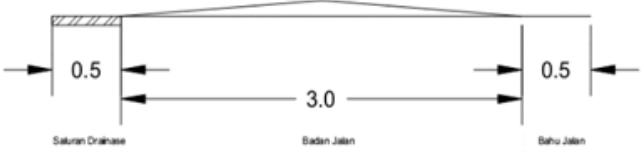

Ket. dalam satuan meter

Gambar 2. Penampang Melintang Ruas Jalan Bukit Gandrung Skala 1:100

Gambar 2. menjelaskan bahwa ruas jalan wisata alam Bukit Gandrung memiliki lebar 4,0 meter dengan panjang $1,4 \mathrm{~km}$, dengan lebar bahu jalan masing-masing $50 \mathrm{~cm}$ dan lebar badan jalan 3,0 meter.

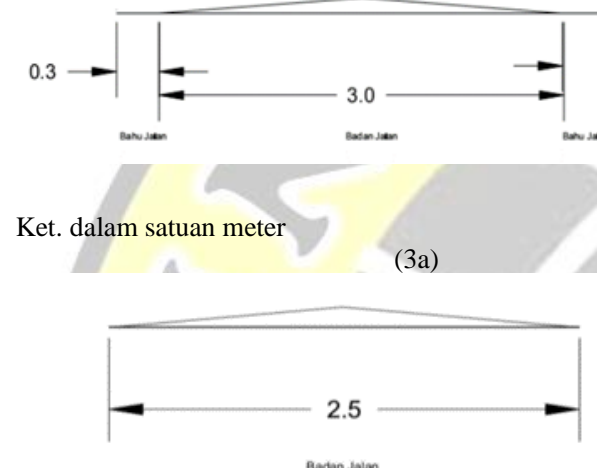

Ket. dalam satuan meter

(3b)

Gambar 3. Penampang Melintang Ruas Jalan Plengsengan Refreshing Hill (PRH) Skala 1:100

Gambar 3. Menjelaskan bahwa ruas jalan wisata alam Plengsengan Refreshing Hill (PRH) terbagi menjadi dua yakni yang pertama dengan lebar 2,5 meter dengan panjang $1 \mathrm{~km}$ yang kedua yakni dengan lebar 3,6 meter dengan panjang 300 meter.
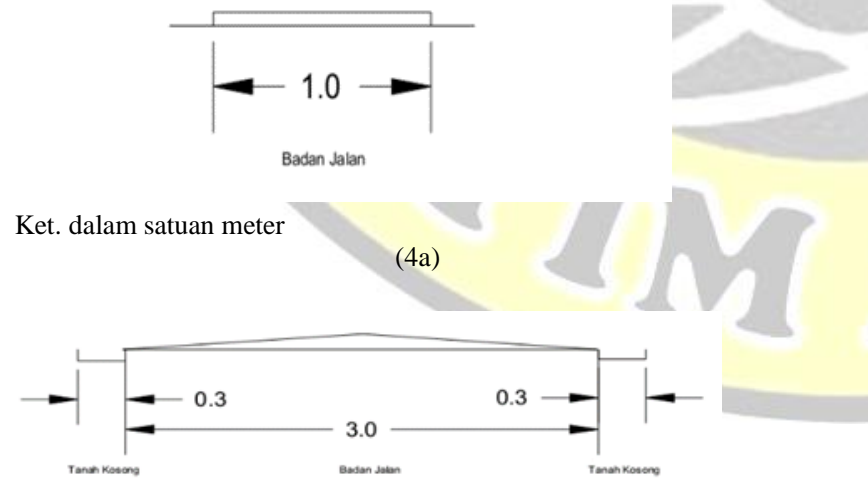

Ket. dalam satuan meter

(4b)

Gambar 4. Penampang Melintang Ruas Jalan Air Terjun Sumber Jodo Skala 1:100
Gambar 4. menjelaskan bahwa ruas jalan wisata alam Air Terjun Sumber Jodo terbagi menjadi dua yaitu yang pertama 3,6 meter dengan panjang 1,5 km dan yang kedua dengan lebar 1 meter panjang 1,2 km.

Dari gambar diatas dapat diketahui perbedaan kondisi dari ketiga ruas jalan wisata alam tersebut. Kondisi lalulintas di ketiga ruas jalan selain dipengaruhi oleh adanya lokasi wisata, juga dipengaruhi oleh kondisi jalan tersebut. Demikian pula kurangnya infrastruktur pendukung di setiap ruas jalan seperti rambu-rambu, pembatas jalan, lampu penerangan, dan bahu jalan juga mempengaruhi arus lalu lintas. Untuk keadaan dari setiap ruas jalan berbeda-beda, baik dari segi keadaan jalan atau infrastruktur yang tersedia. Kondisi ruas jalan Bukit Gandrung cukup curam tanpa adanya lampu penerangan dan pembatas jalan (Gambar 5), kondisi ruas jalan Plengsengan Refreshing Hill (PRH) yang sempit dan curam (Gambar 6), kondisi ruas jalan Air terjun Sumber Jodo sempit dan memiliki keadaan geografi yang tidak sesuai dengan struktur jalan (Gambar 7).
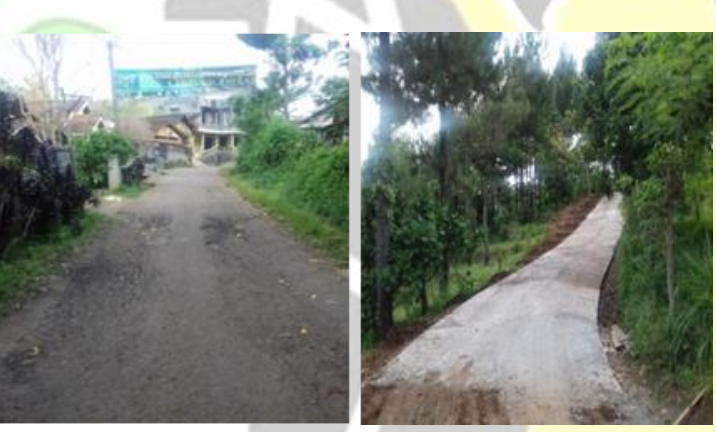

Gambar 5. Kondisi ruas jalan Bukit Gandrung
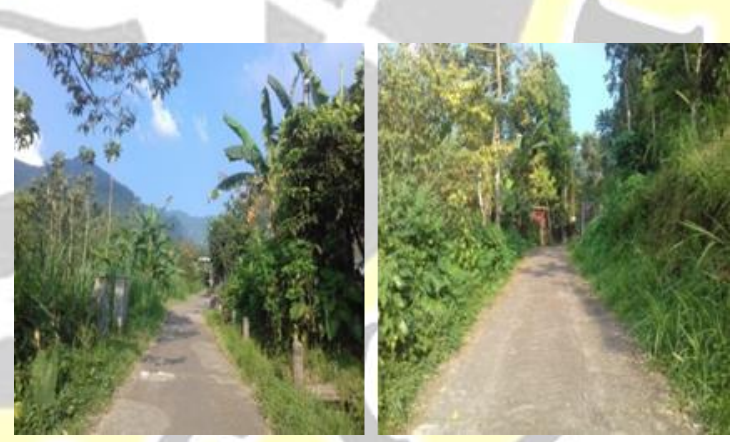

Gambar 6. Kondisi ruas jalan Plengsengan Refreshing Hill (PRH)
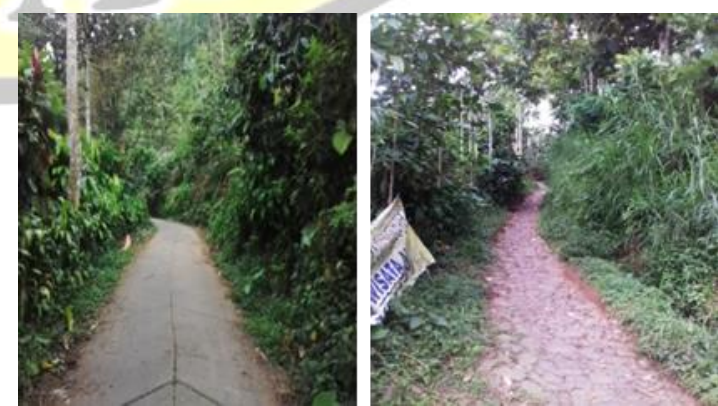

Gambar 7. Kondisi ruas jalan Air Terjun Sumber Jodo 


\section{Analisis LOS (Level Of Service)}

a. Berdasarkan hasil perhitungan volume lalu lintas pada jam puncak di ketiga ruas jalan jalan wisata alam Desa Medowo didapatkan hasil:

1) Wisata Alam Bukit Gandrung diperoleh pada hari Jumat pagi $\mathrm{V}_{\mathrm{mak}}=19,6 \mathrm{smp} / \mathrm{jam}$, Jumat sore $\mathrm{V}_{\mathrm{mak}}=22,2 \mathrm{smp} / \mathrm{jam}$, Minggu siang $\mathrm{V}_{\mathrm{mak}}=33 \mathrm{smp} / \mathrm{jam}$, dan Minggu sore $\mathrm{V}_{\text {mak }}=29,2 \mathrm{smp} / \mathrm{jam}$.

2) Wisata Alam Plengsengan Refreshing Hill $(\mathrm{PRH}), \quad$ Pada hari Jumat pagi $\mathrm{V}_{\text {mak }}=31,3$ smp/jam, hari Jumat sore $\mathrm{V}_{\text {mak }}=25,3$ smp/jam, hari Sabtu pagi $\mathrm{V}_{\mathrm{mak}}=27$ smp/jam, dan hari Sabtu sore $V_{m a k}=34,6$ smp/jam.

3) Wisata Alam Air Terjun Sumber Jodo, pada hari Selasa pagi $\mathrm{V}_{\mathrm{mak}}=22,6 \mathrm{smp} / \mathrm{jam}$, hari Selasa siang $V_{\text {mak }}=22,8 \mathrm{smp} / \mathrm{jam}$, hari Minggu pagi $\mathrm{V}_{\mathrm{mak}}=24,5 \mathrm{smp} / \mathrm{jam}$, dan hari Minggu sore $V_{\text {mak }}=25,2 \mathrm{smp} / \mathrm{jam}$.

b. Nilai C atau kapasitas pada ketiga ruas jalan wisata alam Desa Medowo dapat diketahui dengan perhitungan sebagai berikut: $\mathrm{C}=$ $C_{0} \times F C_{W} \times F C_{S P} \times F C_{S F} \times F C_{C S}=1312,84$ smp/jam

c. Dengan mengetahui nilai volume maksimum dan nilai kapasitas di ruas jalan wisata alam desa Medowo, dapat diketahui tingkat pelayanan jalan atau Level of Service (LOS), dengan perhitungan masing-masing di ketiga ruas jalan sebagai berikut:

1) Wisata Alam Bukit Gandrung

- Hari Jumat Pagi (6 April 2018) $\mathrm{V} / \mathrm{C}=19,6 / 1312,84=0,02$

- Hari Jumat Sore (6 April 2018) $\mathrm{V} / \mathrm{C}=22,2 / 1312,84 \quad=0,02$

- Hari Minggu Siang (8 April 2018) $\mathrm{V} / \mathrm{C}=33 / 1312,84 \quad=0,03$

- Hari Minggu Sore (8 April 2018) $\mathrm{V} / \mathrm{C}=29,2 / 1312,84=0,02$

2) Wisata Alam Plengsengan Refreshing Hill (PRH)

- Hari Jumat Pagi (20 April 2018)

$$
\mathrm{V} / \mathrm{C}=31,3 / 1312,84 \quad=0,02
$$

- Hari Jumat Sore (20 April 2018) $\mathrm{V} / \mathrm{C}=25,3 / 1312,84=0,02$

- Hari Sabtu Pagi (21 April 2018) $\mathrm{V} / \mathrm{C}=27 / 1312,84=0,02$

- Hari Sabtu Sore (21 April 2018) $\mathrm{V} / \mathrm{C}=34,6 / 1312,84=0,03$

3) Wisata Alam Air Terjun Sumber Jodo

- Hari Selasa Pagi (24 April 2018) $\mathrm{V} / \mathrm{C}=22,6 / 1312,84 \quad=0,02$

- Hari Selasa Siang (24 April 2018) $\mathrm{V} / \mathrm{C}=22,8 / 1312,84=0,02$

- Hari Minggu Pagi (29 April 2018) $\mathrm{V} / \mathrm{C}=24,5 / 1312,84=0,02$

- Hari Sabtu Sore (29 April 2018) $\mathrm{V} / \mathrm{C}=25,2 / 1312,84=0,02$
Dari data yang diperoleh di ketiga ruas jalan wisata lama Desa Medow, memiliki kondisi lalu lintas yang lenggang dan bebas dari tundaan dengan nilai V/C < 0,04 , tingkat pelayanan jalan $\mathbf{A}$.

\section{Analisis Scenario Planning dengan Metode} SWOT Balanced Scorecard

Dalam melaksankan perencanaan untuk menentukan strategi yang tepat digunakan di masing-masing ruas jalan wisata alam Desa Medowo Kecamatan Kandangan Kediri, beberapa langkah yang harus dilakukan dan diperhatikan dalam tahapan ini adalah:

\section{a. Mengkaji Isu Utama}

Pada penelitian ini, identifikasi isu utama didapatkan dari perhiungan tingkat pelayanan atau Level Of Service (LOS) di ketiga ruas jalan wisata alam Desa Medowo yang memiliki tingkat pelayanan jalan A. Namun, Tingkat pelayanan A tidak diikuti dengan fasilitas jalan yang tersedia. Kompleks pemukiman warga disekitar ruas jalan mengurangi tingkat keamanan pengguna

b. Faktor Kunci dari Isu Utama (Identify Key Forces)

Berdasarkan hasil penelitian pada jam-jam puncak di ketiga wisata alam Desa Medowo yakni:

1) Volume Arus Lalu Lintas

- Wisata Alam Bukit Gandrung

Volume kendaraan pada jam puncak di wisata alam Bukit Gandrung pada hari Jumat pagi $V_{\text {maks }}=19,6 \mathrm{smp} / \mathrm{jam}$, Jumat sore $V_{\text {mahs }}=22,2 \mathrm{smp} / \mathrm{jam}$ pada hari Minggu siang $V_{\text {maks }}=33 \mathrm{smp} / \mathrm{jam}$, Minggu sore $V_{\text {mahrs }}=29,6 \mathrm{smp} / \mathrm{jam}$.

- Wisata Alam Plengsengan Refreshing Hill (PRH)

Volume kendaraan pada jam puncak di wisata alam Plengsengan Refreshing Hill $(\mathrm{PRH})$ pada hari Jumat pagi $V_{\text {maks }}=31,3$ $\mathrm{smp} / \mathrm{jam}$, Jumat sore $V_{\text {maks }}=25,3 \mathrm{smp} / \mathrm{jam}$ pada hari Sabtu pagi $\mathbb{F}_{\text {rwaks }}=27 \mathrm{smp} / \mathrm{jam}$, Sabtu sore $V_{\text {maks }}=34,6 \mathrm{smp} / \mathrm{jam}$.

- Wisata Alam Air Terjun Sumber Jodo Volume kendaraan pada jam puncak di Wisata Alam Air Terjun Sumber Jodo pada hari Selasa pagi $V_{\text {maks }}=22,6 \mathrm{smp} / \mathrm{jam}$, Selasa siang $V_{\text {maks }}=22,8 \mathrm{smp} / \mathrm{jam}$ pada hari Minggu pagi $V_{\text {maks }}=24,5 \mathrm{smp} / \mathrm{jam}$, Minggu sore $V_{\text {maks }}=25,2 \mathrm{smp} / \mathrm{jam}$.

2) Kapasitas Jalan

Untuk nilai $\mathrm{C}$ rasio pada ketiga ruas jalan wisata alam Desa Medowo Kecamatan Kandangan dapat diketahui dengan perhitungan sebagai berikut 1312,84 smp/jam.

3) Tingkat Pelayanan

Tingkat pelayanan untuk ketiga ruas jalan Wisata Alam Desa Medowo Kecamatan Kandangan Kediri didapat nilai antara 0,020,03 , sehingga dalam tingkat pelayanan A pada 
jam-jam sibuk, dimana pengendara lenggang dan dengan bebas menentukan kecepatan.

c. Mengkaji SWOT Balanced Scorecard

Dari ketiga ruas jalan akan dikaji dari ke 4 (empat) faktor SWOT Balanced Scorecard, dan kemudian disimpulkan dari hasil anallisis dan dilakukan penilaian terhadap variabel terpilih yang terdiri dari 4 variabel yaitu kekuatan, kelemahan, peluang, dan ancaman (Tabel 2).

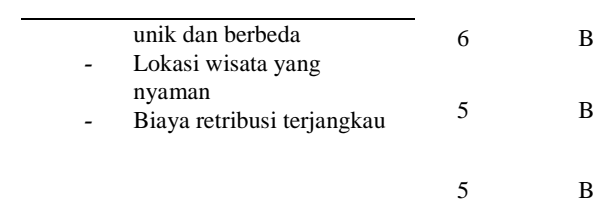

2. Kelemahan Manajemen bersifat individual Belum dikenal luas oleh masyarakat

Tabel 2. Penilaian Terhadap Kriteria

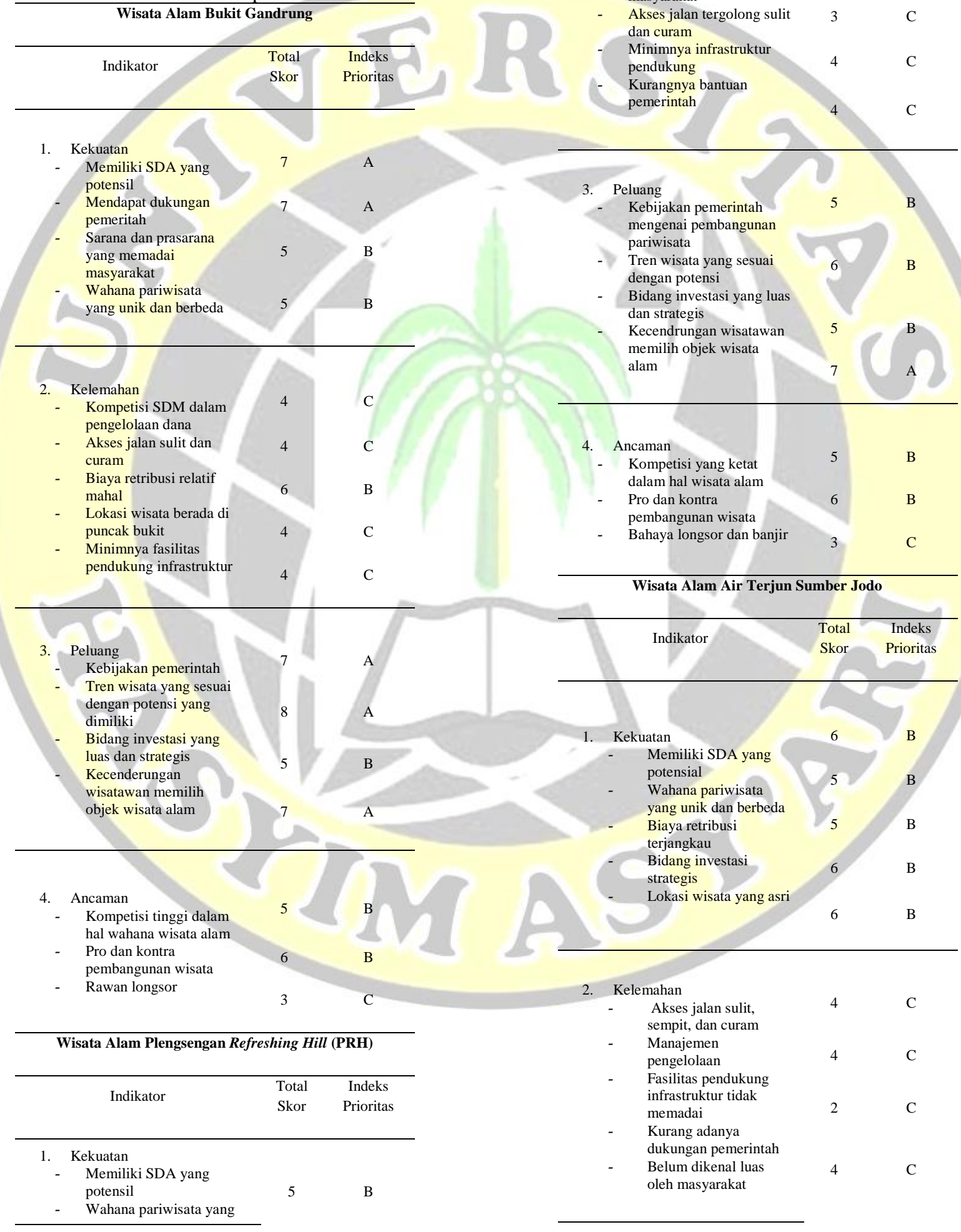




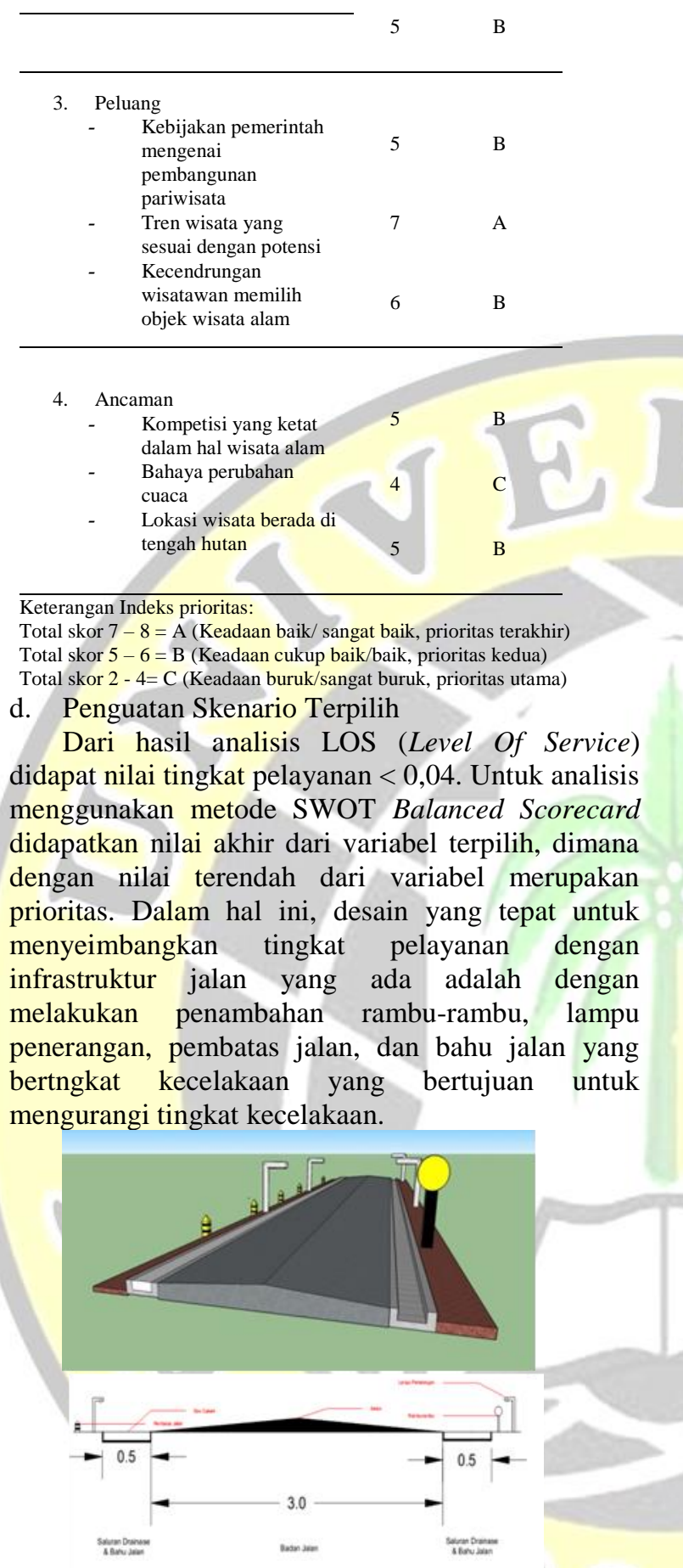

Gambar 8. Desain Ruas Jalan Wisata Alam Bukit Gandrung
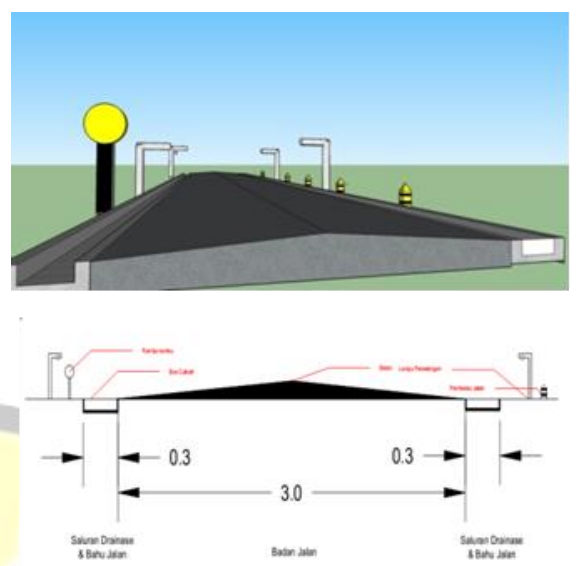

Gambar 9. Desain Ruas Jalan Wisata Plengsengan Refreshing Hill (PRH)

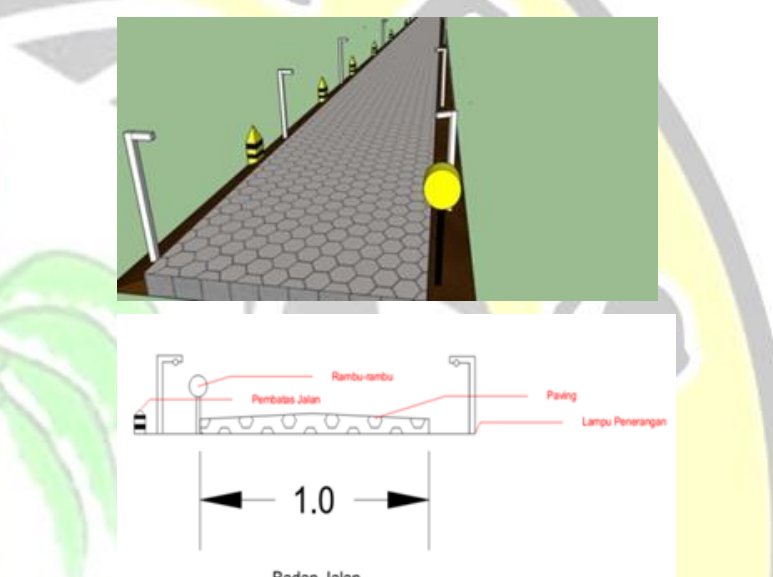

Gambar 10. Desain Ruas Jalan Wisata Alam Air Terjun Sumber Jodo

\section{PENUTUP}

\section{Simpulan}

Berdasarkan dari hasil penelitian dan perhitungan LOS (Level Of Service) dan SWOT Balanced Scorecard, didapatkan urutan prioritas penanganan variabel untuk ketiga ruas jalan wisata alam Desa Medowo berdasarkan 5 kriteria (kenyamanan, keamanan, kesenangan, daya tarik, dan geometrik jalan) dan 4 variabel (kekuatan, kelemahan, peluang, dan ancaman) dengan nilai variabel kurang dari atau sama dengan 4 adalah perbaikan jalan dan penambahan infrastruktur pendukung seperti ramburambu, lampu penerangan, pembatas jalan, dan bahu jalan.

\section{Saran}

Untuk proses penanganan variabel terpilih diperlukan kerjasama yang lebih baik antara lembaga dengan masyarakat dimana hal itu dimaksudkan untuk meminimalisir adanya kegiatan diluar jangkauan yang dapat mencelakai pengguna jalan. Untuk peneliti selanjutnya diharapkan : 
a. Meminimalkan kesalahan dalam penulisan ataupun perhitungan kinerja lalu lintas dengan melibatkan tiga atau lebih lokasi sekaligus.

b. Menyajikan solusi yang lebih dari sekedar perencanaan jalan dan infrastrukturnya, seperti pemecahan masalah mengenai struktur pondasi untuk bangunan lokasi wisata yang berada di lereng bukit atau tepi sungai.

c. Mengenali kebutuhan dan potensi dari masingmasing objek agar dapat dengan tepat merencanakan solusi penanganan.

\section{DAFTAR PUSTAKA}

Amudi, Abdiyah, dkk. 2015. Evaluasi Kinerja Lajur Khusus Sepeda dan Becak di Jalan KH. Wahid Hasyim Kabupaten Jombang. Jurnal Rekayasa Sipil. Vol. 9 (2) .

Dedek Ariansyah, Sugiarto, Sofyan M Saleh. 2017. Studi Dampak Lalu Lintas Kawasan Akibat Pembangunan Jalan Layang (Flyover) Simpang Surabaya dan Jalan Lintas Bawah (Underpass) Kuta Alam Kota Banda Aceh. Jurnal Teknik Sipil. Vol. 1 (1).

Feby Ayu Lestari. 2014. Analisis Dampak Lalu Lintas Akibat Adanya Pusat Perbelanjaan Dikawasan Pasar Pagi Pangkalpinang Terhadap Kinerja Ruas Jalan. Jurnal Teknik Sipil. Vol. 2 (1).

F.C Woran. 2015. Analisa Dampak Pembangunan Hotel Ibis Manado Terhadap Lalu Lintas di Jalan Piere Tendean Manado. Jurnal Ilmiah Media Engineering. Vol. 5 (1).

Rahman, Yudha, Mohammad Muktialie. 2014. Pengaruh Aktivitas Pantai Taplau Kota Padang Terhadap Ekonomi, Sosial, Masyarakat, dan Lingkungan. Jurnal Teknik PWK. Vol. 3 (4).

Tonaas Rantung. 2016. Analisa Dampak Lalu Lintas (Andalalin) Kawasan Lippo Plaza Kairagi Manado. Jurnal Ilmiah Media Engineerig Vol. 5 No.1.

Woro Aryani, Sandra, dkk. 2017. Analisis Dampak Pembangunan Pariwisata pada Aspek Ekonomi dan Sosial Budaya Masyarakat. Jurnal Administrasi Bisnis. Vol. 49 No. 2.
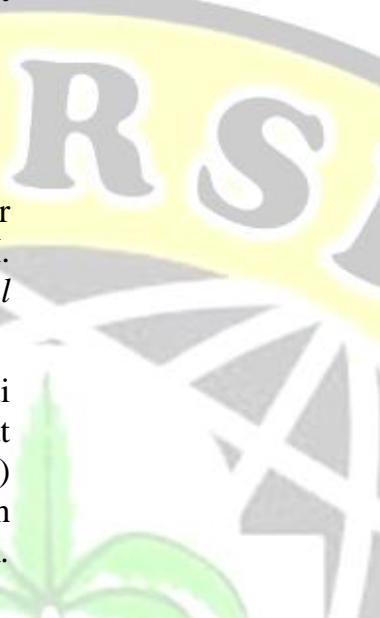
Q1 